\title{
New species and nomenclatural notes in Lobobrachus Sharp (Coleoptera, Carabidae, Pterostichini)
}

\author{
Carlos Campaner ${ }^{1} \&$ Kipling W. Will ${ }^{2}$ \\ 1 Universidade de São Paulo (USP), Museu de Zoologia (MZUSP). São Paulo, SP, Brasil. \\ ORCID: http://orcid.org/0000-0002-4271-2263. E-mail: campaner@usp.br \\ ${ }^{2}$ University of California Berkeley, Essig Museum of Entomology. Berkeley, California, United States. \\ ORCID: http://orcid.org/0000-0002-7056-9011. E-mail: kipwill@berkeley.edu
}

\begin{abstract}
A new species of Lobobrachus Sharp, 1885, Lobobrachus cleidecostae sp. nov., from Piauí state, Brazil, is described and illustrated. The genus and Lobobrachus lacerdae Sharp, 1885, are redescribed and the identity of L. alternans Tschitschérine, 1901 , is discussed. Based on study of all available specimens and published descriptions it appears that $L$. alternans cannot be diagnosed and is a synonym of $L$. lacerdae. However, the syntypes of $L$. alternans cannot be located, thereby making a final decision on synonymy impossible to substantiate fully. Photographs of the aedeagi of L. lacerdae, L. cleidecostae, and specimens that best correspond to $L$. alternans, including those putatively identified by Tschitschérine, are presented for the first time.
\end{abstract}

Key-Words. Aedeagus; Pterostichini; Euchroina; Taxonomy.

\section{INTRODUCTION}

The tribe Pterostichini Bonelli, 1810, is highly diverse, and is recorded from every continent, except Antarctica. Species can be found from the Arctic regions to the tropics, including regions with cold and temperate to hot and dry climates. The taxonomy of the Neotropical fauna is difficult to assess as revisions are available for only a few of the more than 25 genera. For example, Euchroa Brullé was partially revised by Frania \& Ball (2006), Abaris Dejean revised by Will (2002), Parhypates Motschulsky reviewed by Straneo (1986), and Blennidus Motschulsky covered for some faunas by Straneo (1985, as Sierrobius Straneo; 1993, as Ogmopleura Tschitschérine), Moret $(1995,2005)$ and Giachino \& Allegro (2011) (see Straneo, 1977, 1979; Reichardt, 1977 for older literature treating the tribe). Other genera are known only from their brief original descriptions and scattered, incomplete faunal works.

Within Pterostichini, Sharp (1885) erected the genus Lobobrachus for L. lacerdae Sharp, 1885. The monotypic genus was characterized mainly by large size (25.5 mm), bright metallic colors, broad mentum with short lateral lobes, last labial and maxillary palpomeres securiform, absence of setae on the prosternal process, and three setae on each side of the prothorax (Fig. 1). Tschitschérine (1901a) described the second species of the ge- nus, L. alternans, asserting it differed from L. lacerdae by darker coloration, prominence of the humeral angles and more acute posterior angles of pronotum, and like Sharp (1885), he did not present a study of genitalia.

Herein, the diversity of genus Lobobrachus is reviewed and a new species $L$. cleidecostae from Piauí state, Brazil, is described and illustrated. A thorough comparison of specimens of L. lacerdae and $L$. alternans, including the first-hand study of the male genitalia, showed no consistent morphological differences between species other than coloration. The identity of the latter is discussed as a probable synonym of $L$. lacerdae.

\section{MATERIAL AND METHODS}

Acronyms of the institutions cited in the text where the types and other examined specimens are deposited: EMEC: Essig Museum Entomology Collection, University of California, Berkeley, USA; NHM: Natural History Museum, London, United Kingdom; MNHN: Muséum National d'Histoire Naturelle, Paris, France; MZSP: Museu de Zoologia da Universidade de São Paulo, São Paulo, Brazil.

Label data of specimens are given verbatim. Information for each specimen is within quotation marks, labels are separated by double slashes $(/ /)$, and single slashes $(/)$ separate lines on the 
same label. Additional information is given within square brackets.

General morphological terminology used in the descriptions follows Arndt et al. (2016).

Photographs were taken with Canon EOS Rebel T3i camera with Canon MP-E $65 \mathrm{~mm}$ macro-lens and StackShot macro-rail. Multi-focus images were combined with Zerene Stacker version 1.04. Images were edited for clarity in Adobe Photoshop CS6.

\section{RESULTS}

\section{Lobobrachus Sharp}

(Figs. 1-7, 9-21)

Type species: Lobobrachus lacerdae Sharp, 1885: 403, by monotypy.

Straneo, 1977: 115, 1979: 347; Lorenz, 2005: 261 (cat.); Blackwelder, 1944: 34 (cat.); Reichardt, 1977: 407; Bousquet, 2012: 50 (cat.).

Diagnosis: Large size, remarkable bright metallic colors; labial and maxillary palpomeres securiform; paraglossae apically glabrous; prosternal process glabrous; pronotal margin with three setae (Fig. 1); and abdominal ventrite 6 with small punctures near margin.

Redescription: Size and form: Large, 22.5-30.5 mm, deep bodied, elongate and slightly depressed beetles.

Color: Black with forebody deep, metallic bronze, aeneous or blue; elytra metallic cupreous with margins frequently gold or aeneous and intervals 1, 3, and 5 darker, less metallic or lacking metallic color. Ventrally, legs and antennae black. Palps piceous.

Luster and microsculpture: Moderately shiny, isodiametric microsculpture throughout, less evident on head, slightly stretched on pronotum, clearly evident and slightly dull on elytra.

Head: Relatively broad, longer than wide, wider behind eyes, and slightly narrower than anterior margin of pronotum; eyes moderately prominent; ocular ratio 1.27-1.42. Frontal impressions deeply impressed from fronto-clypeal suture to near level of anterior supra-orbital seta, divergently curved. Antennae filiform, moderately long, reaching basal forth of pronotum or longer; antennomeres 1-3 glabrous except for one to many long setae near apices; antennomeres 4-11 densely pubescent except narrow basal band. Clypeus relatively long, slightly emarginate anterior margin, single apicolateral seta well removed from anterior margin. Labrum relatively large, anterior margin convex; six marginal setae with lateral two (one each side), four to six times length of two medial pairs and lateralmost seta widely separated from medial pairs. Mandibles heavily built, scrobe shallow and broad. Maxillary and labial apical palpomeres notably securiform. Mentum short, transverse, epilobes scarcely more prominent than medial tooth; one paramedial pair of setae subtending tooth; tooth of mentum very broad, short and shallowly emarginate; paramedial pits very large and extremely deep. Submentum with single lateral seta; gular pits deep; gula about as wide as mentum tooth. Ligular sclerite very wide, apex broadly rounded with a single pair of long setae.

Thorax: Pronotum median length slightly longer than maximum width. Front angles not at all produced. Posterior angles slightly acute. Lateral margins evenly curved from anterior margin to posterior fourth, then sinuate and straight onto posterior angles. Neither base not apical margins beaded. A short, shallow submarginal sulcus visible very near anterior angles in some specimens. Lateral bead thick, narrowing apically and just at posterior angles. Medial impression deep, ended just short of anterior and posterior margins. Lateral-basal impression very deep, divergent, extended to posterior margin, and separated from side margins by a convexity. Two anterior latero-marginal setae and a single seta touching lateral bead about one pore-width distant from posterior margin (each side; six setae total). Elytra elongate ovoid, apically clearly sinuate. Basal margin complete from humeri to parascutellar stria. Scutellum broad, extended slightly past basal margin. Humeral tooth rounded, very little or not at all prominent or somewhat sharp and prominent. Parascutellar punctures present near base of stria 2. Parascutellar striae and angular base of stria 1 variably impressed, but typically evident at least in part. Nine elytral striae deeply impressed, punctate, slightly crenulate. Intervals convex, intervals $1,3,5$, and 7 notably more convex than adjacent intervals; 3,5 , and 7 much broader than adjacent intervals. Discal punctures variable in number and position even between sides in an individual, each elytron with one [but up to three unilaterally] in interval 3. Stria 7 with two or rarely three umbilicate punctures near apex. Striae 8 with around 24 umbilicate marginal punctures distributed along its length. Stria 9 with a single umbilicate puncture near humeral angle. Lateral margin with distinct or slight sinuation near base, subtended by a punctate sulcus on epipleura. Plica large, externally visible and in repose fitted to a large lobe of abdominal ventrite 6 . Metepisterna very short, anterior width greater than length. Metepimeron very short, wide, with convex posterior margin. Completely apterous. Metacoxal sulcus sinuate near lateral end. Tarsomeres of all legs smooth and glabrous dorsally; meso- and meta-tarsomeres with lateral sulci shallowly impressed or rarely absent. Tarsomere 5 of all legs with two rows of stout ventral setae. Protarsomeres (Figs. 2A-3A) of male expanded apically, tarsomeres 1-3 ventrally with two rows of squamous setae; in female (Figs. 2B-3B) little expanded, lacking squamous setae. Two setae subtending tarsal claw. Meso- and meta-tibia with well-developed apical ctenidium. Mesotibia with dorsal, longitudinal strigose band.

Abdomen: Ventrites 3-6 with complete, transverse sulcus; 3-5 with single paramedial pair of setae; apical margin of ventrite 6 with three pairs of setae in male and five 

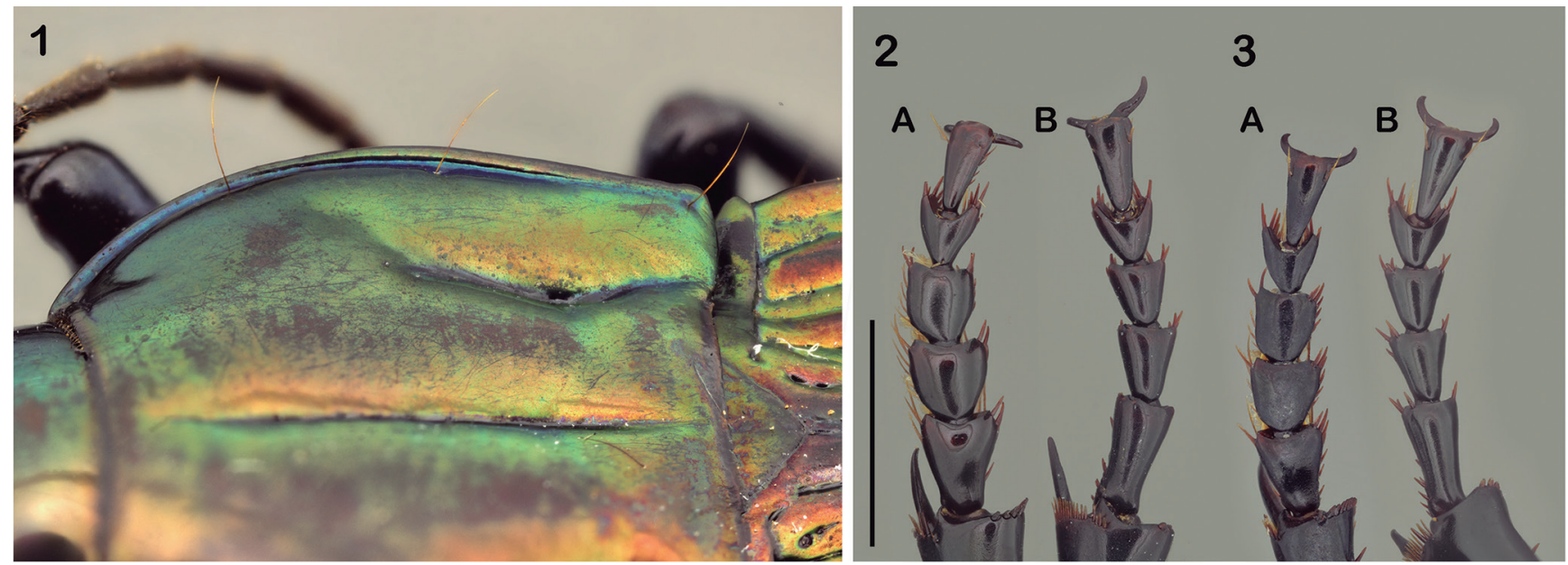

Figures 1-3. Morphology of Lobobrachus species. (1) L. cleidecostae sp. nov., lateral half of pronotum; (2-3) protarsomeres of (A) males and (B) females. (2) L. lacerdae Sharp and (3) L. cleidecostae sp. nov. Scale bar: $2.0 \mathrm{~mm}$.

to seven pairs in female, set in shallow punctures near apical margin. Male genitalia: left side up in repose; ostium of median lobe positioned dorsally.

Distribution: Brazil (Piauí, Paraíba, Pernambuco, Bahia and Minas Gerais states).

\section{Lobobrachus lacerdae Sharp}

(Figs. 2, 4-6, 13-15)

Lobobrachus lacerdae Sharp, 1885: 403; Tschitschérine, 1901a: 2; 1901b: 69; Blackwelder, 1944: 34 (cat.).

Type material examined (by photographs): 2 SYNTYPES (NHM): Bahia//Lacerda/ Bahia, [Brazil]// Fry coll./1905-100.

Additional material examined: "Brazil. PI [Piauí], prox. caracol / Pq. Nac. Serra das / Confusões, 11-29-I-02 [2002] / Montingelli, G.G. col (5 ơ, 5 ᄋ, MZSP)”; "Brasil, PI [Piauí], P.N. Serra das / Confusões / lagoa Jacú / out.2000, (2 o", MZSP)"; "Brasil, BA [Bahia] / central. Pit Fall / III.2000 / F. Cunha. E.F. Ramos (1 ơ, 4 \%, MZSP)"; "Bonfin / (= Vila Nova) BA, [Bahia. Brazil] / 1908 / E. Garbe col. // 19278 (1 ơ, MZSP)"; "de S. Antonio da Barra, [Bahia, Brazil] / à Villa Victoria / Ch. Pujol 1890 (1 ơ, MZSP)"; "Pedra Azul / M.Gerais - Brasil, [Minas Gerais] / XII-1970 / F.M. Oliveira (1 9, MZSP)"; "S.Antonio da Barra / Pr. De Bahia / Gounelle 11-12.88 // MUSEUM PARIS / COLL E. GOUNELLE 1915 // Labobrachus / Lacerdae / Sharp [sic., handwritten, green border] (1 \&, MNHN)"; "S.Antonia da Barra / Pr.de Bahia / Gounelle 11-12.88 // MUSEUM PARIS COLL. E. GOUNELLE 1915 (1 o", MNHN)"; "Lobobrachus nov. g / lacerdae H.D. / Brazil [male genitalia glued to card, underside of genitalia card has "lacerdae"] (1 o", EMEC)".

Redescription: As in the genus description above and total length: 22.5-30.5 mm; length of elytron, 13.2-19.0 mm; humeral width, $5.2-7.5 \mathrm{~mm}$. Coloration: head and pronotum with metallic green, some areas with violet iridescent reflection; elytra entirely reddish-copper or with some greenish-copper intervals; humerus, epipleura and scutellum greenish-copper; mouthparts, legs and ventral region black; antennae with three first antennomeres black and remaining antennomeres paler piceous to brown. Aedeagus (Figs. 13-15). Median lobe curved with distal margin slightly declivous with rounded angles; opening of ostium subelliptical, almost straight-sided at median lobe middle.

Distribution: Brazil (Piauí, Paraíba, Pernambuco, Bahia and Minas Gerais states).

\section{Lobobrachus alternans Tschitschérine}

(Figs. 7-10, 16-18)

Lobobrachus alternans Tschitschérine, 1901a: 2; 1901b: 69; Blackwelder 1944: 34 (cat.).

Material examined tentatively identified as $L$. alternans: "Paraiba / J. Pessôa / [Brasil, PB, João Pessoa], 06-VI-1954" (1 ex., MZSP); "Paraiba / J. Pessôa / [Brazil, PB, João Pessoa] / VII-955 [1955] /, Pe. Pereira" (1 ơ, 2 \%, MZSP); "Serra de Communaty / (Pernambuco) [Brasil] / Gounelle, 1,2,3. 1893" (1 o", MZSP); "Garanhuns / Pernambuco, Brasil / IX-1937 // coleção / M. Alvarenga" (1 ơ, MZSP); "S. Antonio da Barra / Pr. de Bahia, [Brazil, Bahia] / Gounelle, 11.12.88, [11-XII 1888]" (1 ㅇ, MZSP); "Bonfin / (= Vila Nova) BA, [Brazil, Bahia] / 1908 / E. Garbe col." (3 ơ, 1 ex., MZSP); "Serra de Communaty / (Pernambuco) / Gounelle 12.03.1893" (1 \&, MNHN); "Serra de Communaty / (Pernambuco)/ Gounelle 12.03.1893 // MUSEUM PARIS COLL E. GOUNELLE 1915" (1 o', MNHN); "Pernambuco / Brazil / V.D.P. [van der Poll]" (1 \&, EMEC); "144 // Lobobrachus / n.sp. / Brazil (1 \&, EMEC)".

Remarks: Tschitschérine (1901a) described L. alternans from four specimens including males and females collected by P.É. Gounelle in Bahia, Northeast Brazil. Later on, in a short note in the same issue Tschitschérine (1901b: 69) corrected the locality of the specimens as being from "Aguas Bellas" and "Serra da Bernarda" in Pernambuco 
state (not Bahia) and mentions the M. Maindron collection (currently at MNHN) as the specimens' repository. No collection date was given.

Tschitschérine (1901a) based his diagnosis of this species as separate from $L$. lacerdae on a combination of colors: head and pronotum metallic, olive-green or bluish-green; elytra purplish-red or cupreous, intervals 1, 3, 5 and 7 black with a slight green tinge, wider and more prominent than the others; antennae and legs black; and on the greater prominence of the elytral humeral tooth

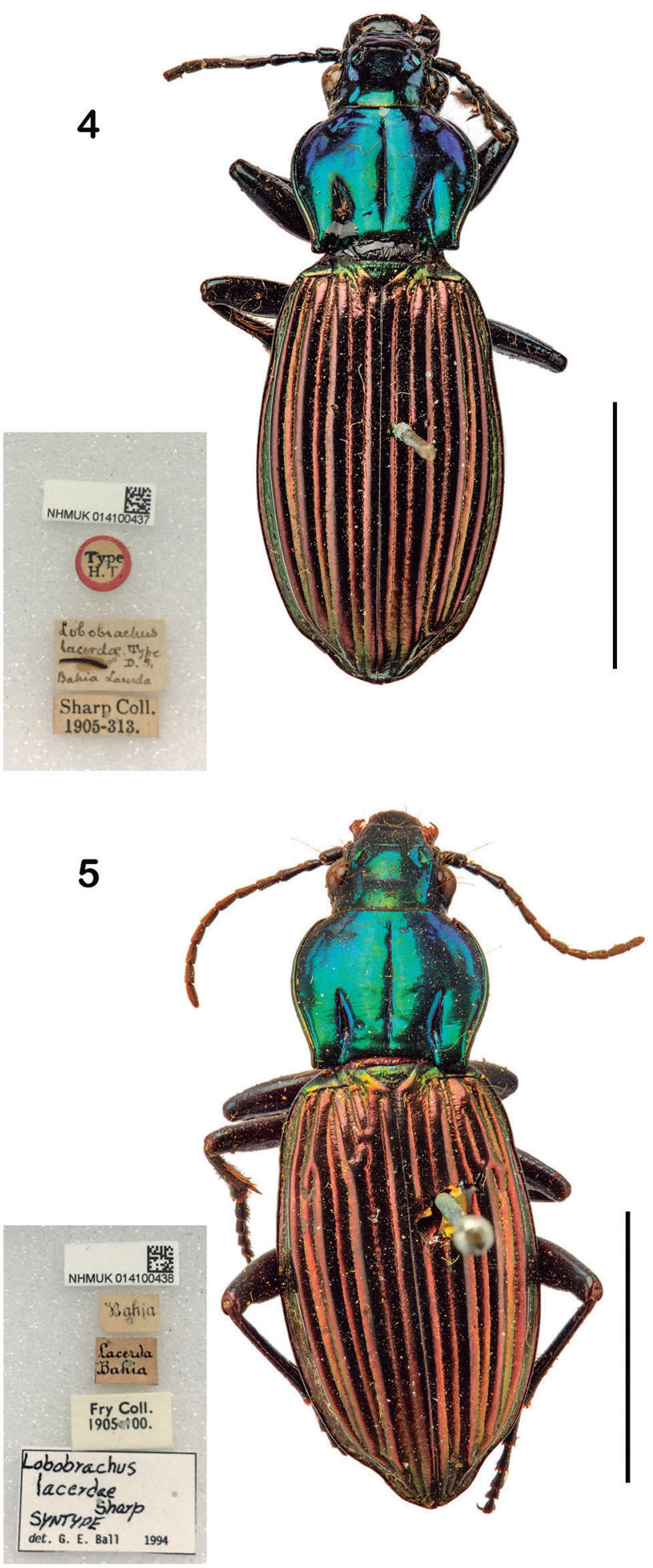

in his species. In the original description of L. alternans, Tschitschérine (1901a) specifically notes his species differs from L. lacerdae by the darker cuprous-purple color of the elytra, and especially by the contrasting black and slightly green coloration of some intervals; as well as the humeral angles having a more pronounced and sharper appearance and the posterior angles of the pronotum being more acute. However, he also noted that "these are variable in L. lacerdae." Indeed, all these described differences are variable among specimens of L. lacerdae. In

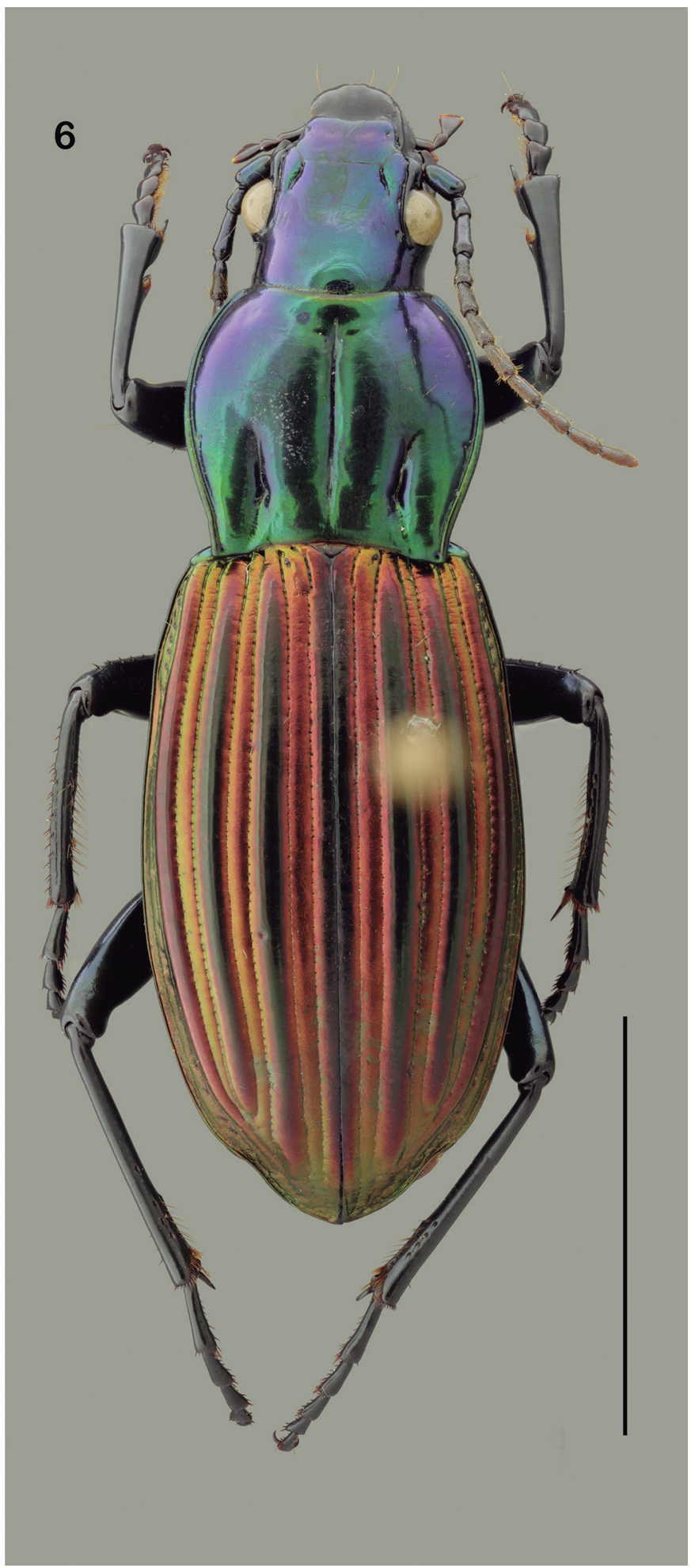

Figures 4-6. Lobobrachus lacerdae Sharp, dorsal habitus. Scale bar: $10 \mathrm{~mm}$. 
addition, in some specimens that otherwise fit well in the concept of $L$. alternans the intervals have the same coloration as the rest of the elytra. Perhaps the type series of $L$. alternans represents one extreme of the variation in characters, which clearly appears as a gradation when more specimens are compared. Neither Sharp (1885) nor Tschitschérine (1901a) described the genitalia of any of the specimens.

Attempts to locate type specimens of L. alternans in the Maindron collection (MNHN) were unsuccessful (MNHN staff, in. litt.). Specimens belonging to the MNHN that were located included male and female pairs identi- fied as each of the Lobobrachus species but without any indication that they were types, nor do the locality labels correspond with the locations reported by Tschitschérine. It is likely, however, that Tschitschérine did examine and identify these specimens. However, in addition to the MNHN specimens, the MZSP and EMEC house specimens of L. alternans that may clarify the species' identity and their putative differences from $L$. lacerdae. One such specimen is a male (Fig. 7) that formerly belonged to the collection of Museu Paulista (MP), later incorporated into the MZSP (see Nearns et al., 2019). It is recorded in their registry book ("Catálogo de Formicidae Vol. II") under
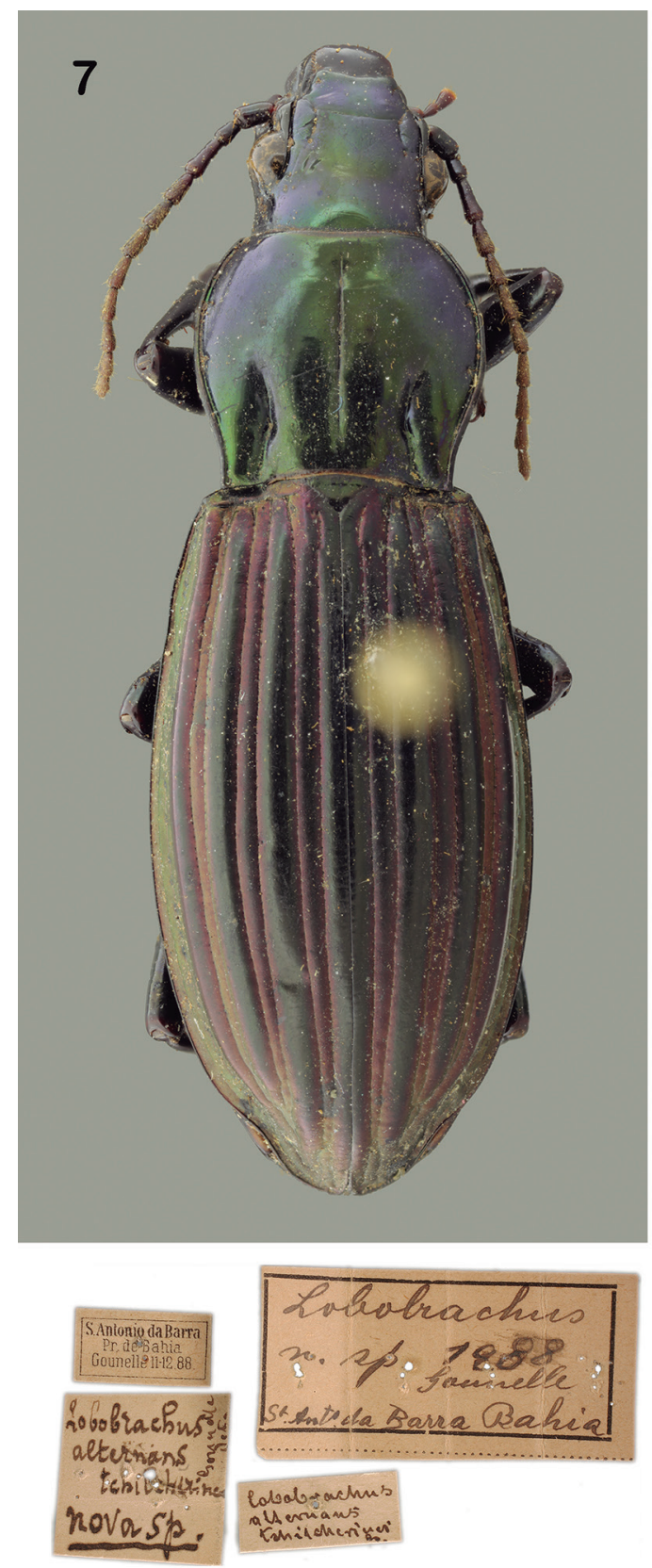

9
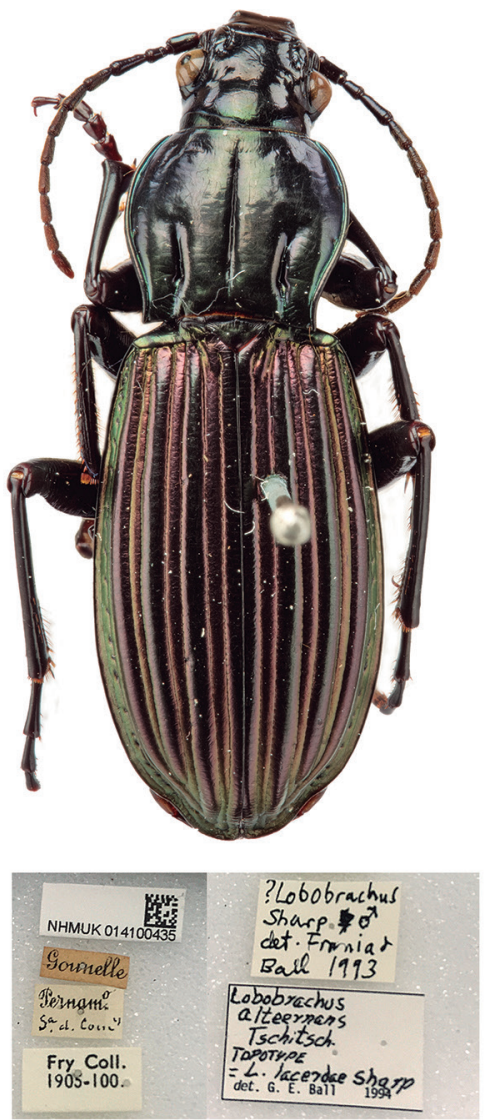
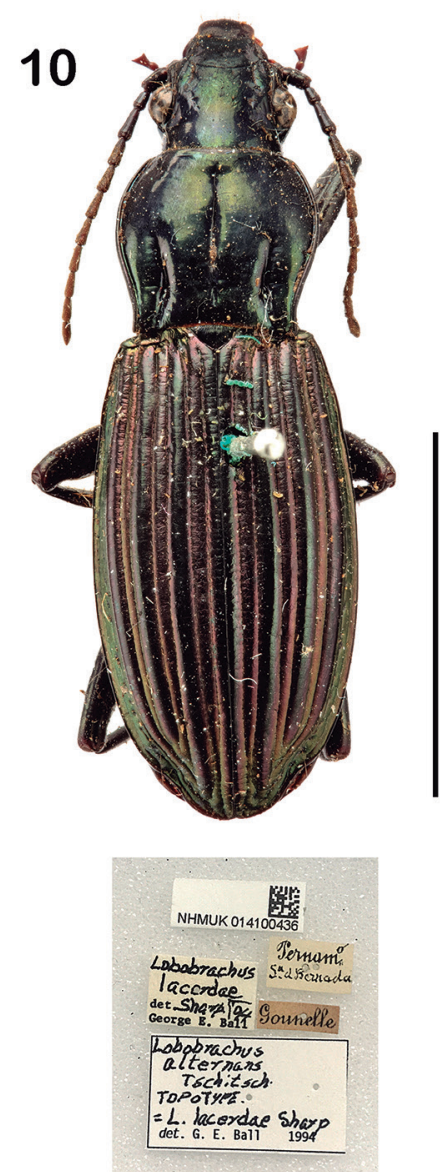

8

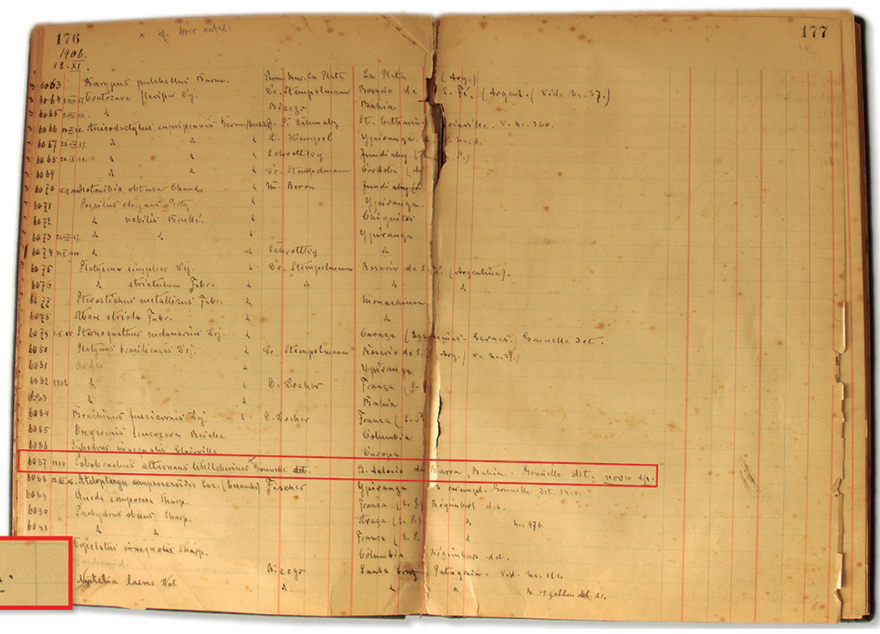

Figures 7-10. "Lobobrachus alternans" Tschitschérine. (7) Habitus, dorsal, specimen from MZSP; (8) registry book; (9-10) dorsal habitus, specimen from NHM. Scale bar: $10.0 \mathrm{~mm}$. 
the number 6087 with the following data: "6087 | 1888 | Lobobrachus alternans Tschitschérines Gounelle det.| St. Antonio da Barra, Bahia Gounelle det. sp. nov." (Fig. 8). This specimen perfectly matches Tschitschérine's (1901a) description and bears Gounelle's original label, from Bahia. Besides Gounelle's label, it was labeled as "Lobobrachus n. sp. 1888, Gounelle, St. Antonio da Barra Bahia." Later, another label was added, now with a full identification: "Lobobrachus alternans Tschitschérine sp. nov. Gounelle det." (Fig. 7). It is not clear, however, when the specimen was labeled as such nor whose determination it is, but it is plausible that it was after the species publication (1901a) by someone aware of it being a duplicate of the type series. Moreover, Tschitschérine was probably aware of Gounelle's original series comprising specimens from Bahia and Pernambuco. According to Papavero (1971), Gounelle collected in Bahia state from November 1888 to 1889 , and in several localities of Pernambuco (including type localities of L. alternans) from June 1892 to March 1893. That specimen (Fig. 7) is assumed here as originally belonging to Gounelle's personal collection - which was later acquired by the MP (Nearns et al., 2019) - and is part of the same series of specimens as the type series of $L$. alternans, although from a different locality and date. The whole series of type and non-type specimens collected by Gounelle is assumed to be composed of specimens from the neighboring states of Bahia and Pernambuco.

A comparison of this and additional specimens of L. alternans with specimens matching the described coloration of $L$. lacerdae from several localities across the Brazilian northeast shows that the aforementioned supposed differences between the two species are indeed intraspecific variations. Moreover, a comparison of the aedeagi (Figs. 13-18) from the various color forms shows no differences, while the male genitalia clearly differ from L. cleidecostae sp. nov. (Figs. 19-21).

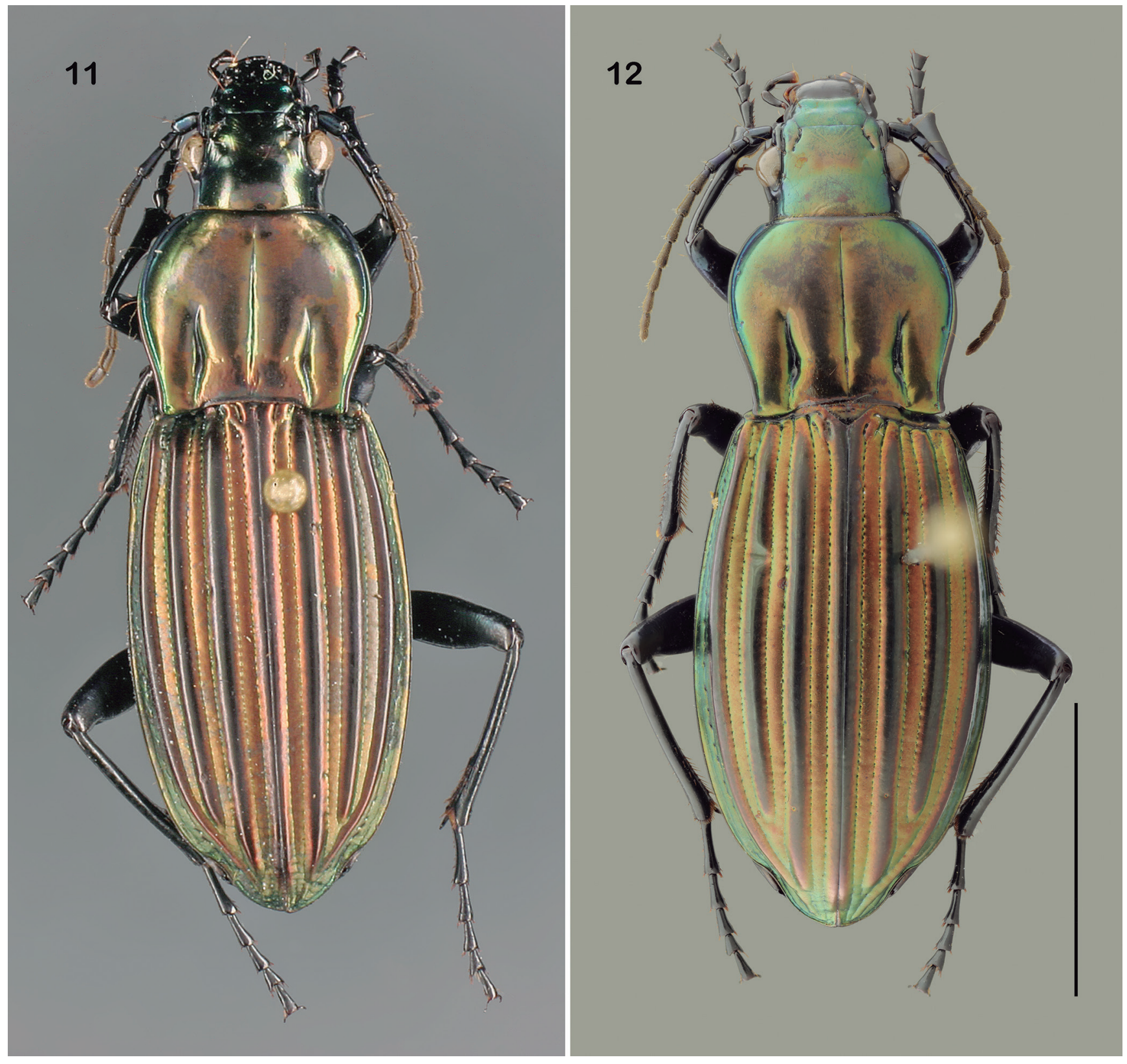

Figures 11-12. Lobobrachus cleidecostae sp. nov., habitus dorsal. (11) Holotype, male; (12) paratype, female. Scale bar: $10.0 \mathrm{~mm}$. 
Additionally, during the search for type specimens for this study, we received photographs from the NHM of the two syntypes of $L$. lacerdae and two specimens identified as L. alternans by the late George E. Ball (University of Alberta, Canada) in 1993 and 1994 (Figs. 9-10). Both L. alternans specimens are also originally from Gounelle, collected in Pernambuco state. One of them is labeled as from "Serra da Bernarda," one of the type localities given in Tschitschérine's (1901b) emendation. These speci- mens are assumed to be from the same series as the type specimens of $L$. alternans. Ball then labeled them as "topotypes" (i.e. from the same type locality) of L. alternans and as synonyms of L. lacerdae Sharp, although as far as we know, such statement has never been formally published. It is not clear whether this proposal of synonyms was based on the study of L. alternans types in MNHN or solely on these topotypes in NHM. Dr. Ball's stored note files did not include any additional information

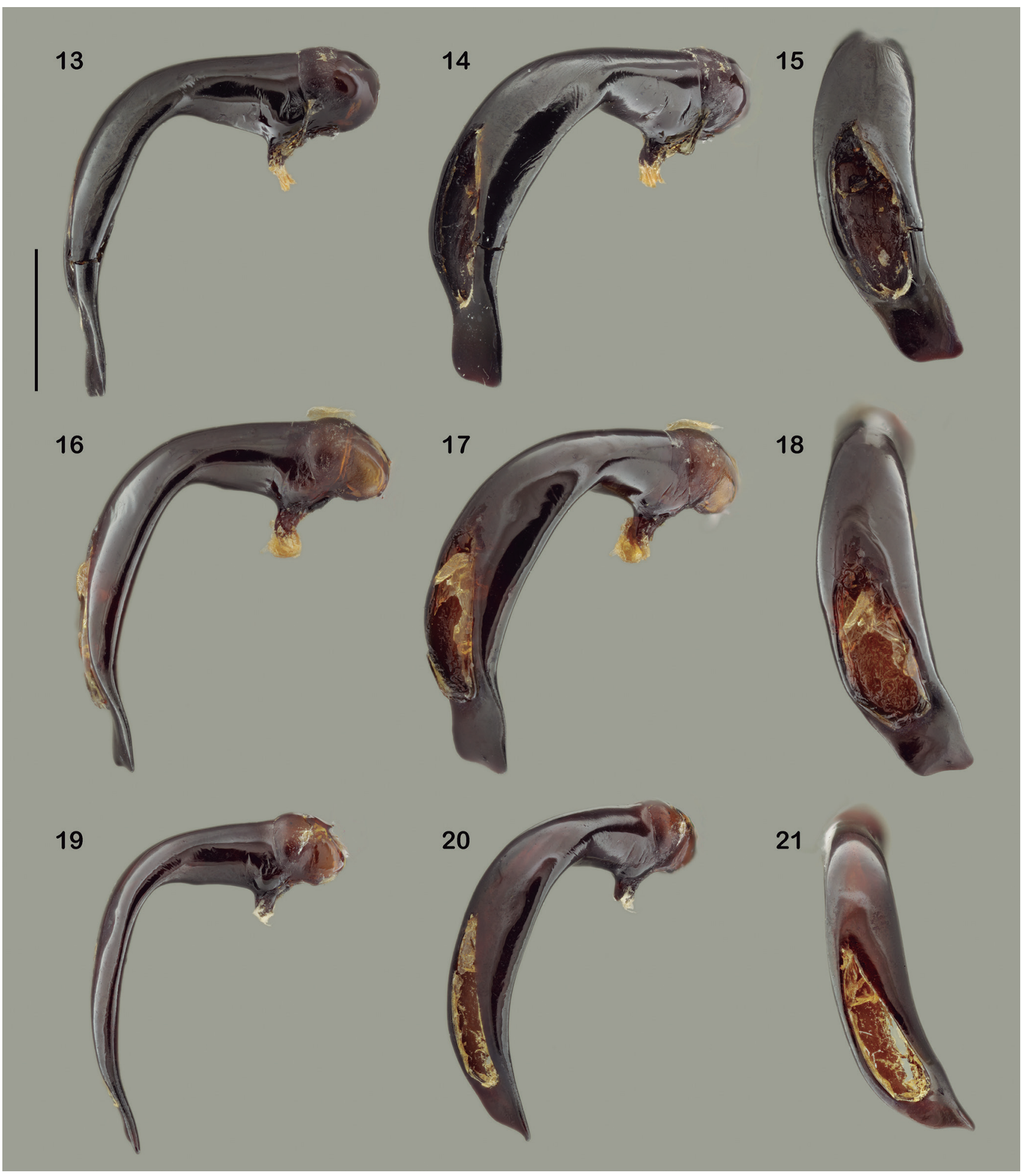

Figures 13-21. Aedeagi of Lobobrachus, right lateral, right latero-dorsal, dorsal: (13-15) Lobobrachus lacerdae Sharp; (16-18) "L. alternans" Tschitschérine; (19-21) L. cleidecostae sp. nov. Scale bar: $2.0 \mathrm{~mm}$. 
about the species or his study (D. Shpeley, $U$ of Alberta in. litt.). It appears that Ball's results and ours converged independently.

Therefore, we conclude that, based on the material available to us and the original descriptions, it is not possible to diagnose $L$. lacerdae and L. alternans as separate species and there is no justification for treating them as such. We used color to group specimens as a working hypothesis, but within-species color variation in carabids has frequently been documented. For example, color variants are known in some species of the putatively closely related genus Euchroa (Frania \& Ball, 2006) and the well-studied South American carabine genus Ceroglossus Solier (Okamoto et al., 2001; MuñozRamírez, 2015). Color, particularly given the variation we observed, is insufficient to recognize these species when neither male genitalia form nor distribution corroborate separation. While the case for synonymy is strong, nomenclature hinges on type specimens. We acknowledge the importance of direct study of actual type specimens in nomenclatural acts. This contribution brings us as far as possible in regard to addressing the species identity and we wait for the type specimens to be located and properly studied to propose formally the taxonomic change.

\section{Lobobrachus cleidecostae sp.nov. (Figs. 1, 3, 11-12, 19-21)}

Type material: HOLOTYPE o" (MZSP 31405): "Brasil-PI [Piauí] / Estação Ecológica Uruçuí-Una / 0852'S / 4457'W / 19-29.I.2001 / Montingelli, G.G. col". PARATYPES: same data as holotype (3 $\$$, MZSP 31406-31408).

Diagnosis: Lobobrachus cleidecostae sp. nov. is characterized by a combination of its coloration (Figs. 11-12): greenish-copper with brassy, irregular patches on the pronotum; relatively more convex (subcarinate) odd-numbered intervals of the elytra; and median lobe of aedeagus (Figs. 19-21) with apex strongly slanted, forming a right lateroapical projection at the tip, relatively thinner blade, and ostium slightly rotated to the left near base.

Description: As in genus description and body length: 23.8-26.0 mm; length of the elytra: 14.9-16.5 mm; humeral width: 6.5-7.5 mm. Coloration greenish-copper, with pronotum with irregular brassy patches and elytra with intervals 2, 4, 6 relatively flat and brassy; mouthparts, legs and ventral region black. Mandibles robust, pyramidal, and short with a short, broad scrobe. Antennae slightly longer than pronotum. Elytra elongate with lateral margins rounded; basal region wider than hind angles of pronotum; subapical region slightly constricted with apices conjointly prominent and rounded; intervals 3, 5, 7 strongly convex to subcarinate. Median lobe curved with distal margin strongly declivous, with one angle very prominent forming a rounded lobe; opening of ostium subelliptical, wider near apex, slightly inclined at middle of median lobe.
Etymology: The specific epithet is based on the name of Dr. Cleide Costa, a noted coleopterologist, whom the lead author had the privilege of working alongside for decades at the University of São Paulo Museum of Zoology.

Distribution: Brazil (Piauí state).

\section{ACKNOWLEDGMENTS}

To Sônia Casari for her support, encouragement, review, suggestions and modifications in parts of text; to Gabriel Biffi, for the contact with the curators of the NHM and MNHN, for review, suggestions, modifications in parts of text and supply of most photos; to Kevin Webb and Maxwell V.L. Barclay (NHM) for sending photos of L. lacerdae and L. alternans; to Giovanna G. Montingelli for offering several specimens of $L$. lacerdae and $L$. cleidecostae collected by herself for this study; to Henrique Marianno for taking some photos of L. cleidecostae; to Antonio Santos-Silva for his suggestions; Keiran Devine for the first English version of most of the text; and to Robert Davidson (Carnegie Museum of Natural History, Pittsburgh), for suggestions that significantly improved a later version of the manuscript.

\section{REFERENCES}

Arndt, E.; Beutel, R.G. \& Will, K.W. 2016. 7.10. Carabidae. In: Beutel, R.G. \& Leschen, R.A.B. (Eds.). Coleoptera, Beetles, Volume 1. Morphology and Systematics (Archostemata, Adephaga, Myxophaga, Polyphaga partim). 2.ed. Berlin, Walter de Gruyter. v. 1, p. 160-188. (Handbook of Zoology: Arthropoda: Insecta)

Blackwelder, R.E. 1944. Checklist of the coleopterous insects of Mexico, Central America, the West Indies and South America. Part 1. Bulletin of the United States National Museum, 185: 1-188.

Bousquet, Y. 2012. Catalogue of Geadephaga (Coleoptera, Adephaga) of America, north of Mexico. ZooKeys, 245: 1-1722.

Frania, H.E. \& Ball, G.E. 2006. Taxonomy and evolution of species of the genus Euchroa Brullé (Subgenus Dyschromus Chaudoir) of Central Mexico and the Island of Hispaniola (Coleoptera: Carabidae: Pterostichini: Euchroina). Bulletin of Carnegie Museum of Natural History, 38: 1-125. D01

Giachino, P.M. \& Allegro, G. 2011. Two new Blennidus (Agraphoderus) species from Peru, with synonymic notes (Coleoptera, Carabidae). Fragmenta entomologica, 43: 19-34.

Lorenz, W. 2005. A systematic list of extant ground beetles of the world (Coleoptera "Geadephaga": Trachypachidae and Carabidae, incl. Paussinae, (icindelinae, Rhysodinae). 2.ed. Tutzing, Published by the author. 502p.

Moret, P. 1995. Contribution à la connaissance du genre néotropical Blennidus Motschulsky, 1865. 1ère partie (Coleoptera, Harpalidae, Pterostichinae). Bulletin de la Société entomologique de France, 100(5): 489-500.

Moret, P. 2005. Los Coleópteros Carabidae del Páramo en los Andes del Ecuador: Sistemática, ecologia y biogeografía. Quito, Museo de Zoologia, Centro de Biodiversidad y Ambiente, Escuela de Biologia, Pontificia Universidade Catolica del Ecuador. 307p. (Monografía 2)

Muñoz-Ramírez, C. 2015. The phylogenetic position of Ceroglossus ochsenii Germain and Ceroglossus guerini Germain (Coleoptera: Carabidae), two endemic ground beetles from the Valdivian forest of Chile. Revista Chilena de Entomología, 40: 14-21. 
Nearns, E.H.; Nascimento, F.E. de L. \& Casari, S.A. 2019. Onciderini Thomson, 1860 (Coleoptera: Cerambycidae: Lamiinae) types of the Museu de Zoologia, Universidade de São Paulo (MZSP), with a brief history of the Coleoptera collection. Insecta Mundi, 0715: 1-27.

Okamoto, M.; Kashiwai, N.; Su, Z.H. \& Osawa, S. 2001. Sympatric convergence of the color pattern in the Chilean Ceroglossus ground beetles inferred from sequence comparisons of the mitochondrial ND5 gene. Journal of Molecular Evolution, 53: 530-538.

Papavero, N. 1971. Essays on the history of Neotropical dipterology: with special reference to collectors (1750-1905). São Paulo, Museu de Zoologia, Universidade de São Paulo. v. 1, vii + 216p.

Reichardt, H. 1977. A synopsis of the genera of Neotropical Carabidae (Insecta: Coleoptera). Quaestiones Entomologicae, 13: 346-493.

Sharp, D. 1885. Description of two new Carabidae from Brazil. Stettiner Entomologische Zeitung, 46: 401-403.

Straneo, S.L. 1977. Chiavi per la determinazione dei generi e sottogeneri dei Pterostichini dell'America del Sud. Bollettino della Società entomologica italiana, 109: 104-116.

Straneo, S.L. 1979. Notes about classifications of the South American Pterostichini with a key for determination of subtribes, genera and subgenera (Coleoptera: Carabidae). Quaestiones entomologicae, 15: 345-356.

Straneo, S.L. 1985. On the genus Sierrobius Straneo, 1951 (Coleoptera: Carabidae: Pterostichini). Annals of Carnegie Museum, 54: 233-245.

Straneo, S.L. 1986. Sui gen. Parhypates Motschulsky (Coleoptera, Carabidae). Atti della Società italiana di Scienze naturali e del Museo civico di Storia naturale di Milano, 183: 221-236.

Straneo, S.L. 1993. Nuove specie del genere Ogmopleura Tschitschérine (Coleoptera, Carabidae, Pterostichini) del Perù e dell'Ecuador e chiave per la loro determinazione. Annali del Museo civico di Storia naturale di Genova, 89: 351-399.

Tschitschérine, T.S. 1901a. Description de quelques nouvelles espèces de la tribu Platysmatini. Horae Societatis Entomologicae Rossicae, 35: 01-16.

Tschitschérine, T.S. 1901b. Note sur quelques Platysmatini nouveaux ou peu connus. Horae Societatis Entomologicae Rossicae, 35: 49-72.

Will, K.W. 2002. Revision of the New World Abariform Genera Neotalus N. Gen. and Abaris Dejean (Coleoptera: Carabidae: Pterostichini (Auctorum). Annals of the Carnegie Museum, 71: 143-213. 